\title{
部分的に緊張力を与えた当て板接着鋼板の はく離曲げモーメント
}

\author{
清水 優 $^{1} \cdot$ 石川敏之 ${ }^{2} \cdot$ 服部篤史 ${ }^{3} \cdot$ 河野広隆 $^{4}$ \\ 1正会員 名古屋大学助教 工学研究科社会基盤工学専攻（ $\bar{T} 464-8603$ 愛知県名古屋市千種区不老町） \\ E-mail: shimizu@civil.nagoya-u.ac.jp \\ 2正会員 関西大学准教授 環境都市工学部都市システム工学科（テ564-8680大阪府吹田市山手町3-3-35） \\ E-mail: t-ishi@kansai-u.ac.jp \\ 3 正会員 京都大学准教授, 工学研究科都市社会工学専攻（† 615-8540 京都府京都市西京区京都大学桂） \\ E-mail: hattori.atsushi.7z@kyoto-u.ac.jp \\ 4正会員 京都大学教授, 工学研究科都市社会工学専攻（二615-8540 京都府京都市西京区京都大学桂） \\ E-mail: kawano.hirotaka.8n@kyoto-u.ac.jp
}

\begin{abstract}
経年劣化や設計荷重の変更によって耐荷力が不足した鋼部材に対して，当て板を接着して補強する方法 が行われ始めている．さらに，施工事例は少ないが，緊張力を与えた当て板を鋼部材に接着することで鋼 部材にプレストレスを導入する方法が一部で用いられている。一方，当て板に緊張力を与えて接着する場 合には, 緊張力の解放時に接着剂にせん断応力や垂直応力が作用するため, 小さな荷重で当て板がはく離 してしまう可能性がある，当て板に緊張力を与えて接着する際のはく離荷重を向上するため，当て板端部 に非緊張部を設ける方法が提案されている，本研究では，当て板の端部を除く範囲に緊張力を与えられる 装置を用いて当て板に部分的に緊張力を与え，プレストレス導入量やはく離荷重を検証した．その結果， 当て板端部に非緊張部を設けた場合であっても, 当て板接着中央部では当て板全体を緊張したときと同等 のプレストレスが導入されることがわかった。 また，非緊張部を設けた試験体と当て板全体を緊張した試 験体では，非緊張部を設けた方がはく離荷重が大きくなった。さらに，接着剤に生じる主応力を用いては く離荷重の向上効果を定量的に評価した.
\end{abstract}

Key Words : pre-tensioned, debonding, adhesive, steel plate, strengthening

\section{1. はじめに}

経年劣化や設計荷重の変更によって而荷力が不足した 鋼部材に対して，炭素繊維強化樹脂(CFRP)板や鋼板など の当て板を接着する方法が用いられ始めている1).5).さ らに，当て板にあらかじめ緊張力を導入して接着するこ とによって被着体にプレストレスを導入する方法も開発 されており, 一部のコンクリート部材や鋼部材の補強に 用いられている(8).この補強方法では，プレストレス による死荷重応力の低減および当て板と被着体の合成に よる活荷重応力の低減が期待される.

当て板に緊張力を導入する方法には, 当て板の一端を 定着具で被着体に固定し油圧ジャッキ等で緊張する方法 と，図-1 に示すようにあらかじめ緊張した当て板を接 着し接着剤の硬化後に補強材の緊張力を解放する方法が ある. 後者の方法は，橋梁本体にボルト孔などを設ける ことなく設置することができ, 被着体の外観上の変化が

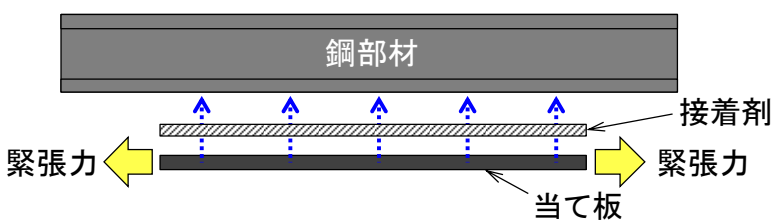

(a) 緊張力を与えた当て板の接着

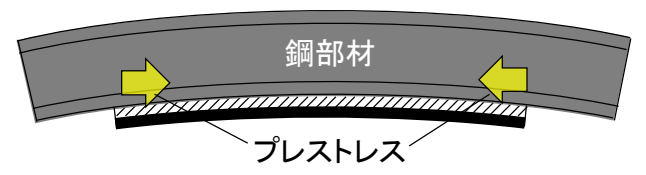

(b) 当て板の緊張力の解放

図-1 緊張力を与えた当て板を接着することに よる鋼部材へのプレストレスの導入 
表-1 試験体

\begin{tabular}{|c|c|c|c|c|c|c|c|c|c|}
\hline \multirow[b]{2}{*}{ 試験体 } & \multicolumn{3}{|c|}{ 母材鋼板 } & \multicolumn{3}{|c|}{ 当て板 } & \multirow[b]{2}{*}{$\begin{array}{c}\text { 接着剤厚さ } \\
\text { [mm] }\end{array}$} & \multirow[b]{2}{*}{$\begin{array}{c}\text { 導入ひずみ } \\
\varepsilon_{p r e}[\mu]\end{array}$} & \multirow[b]{2}{*}{$\begin{array}{c}\text { 非緊張部長さ } \\
l_{n}[\mathrm{~mm}]\end{array}$} \\
\hline & $\begin{array}{c}\begin{array}{c}\text { 幅 } \\
{[\mathrm{mm}]}\end{array} \\
\end{array}$ & $\begin{array}{l}\text { 板厚 } \\
{[\mathrm{mm}]}\end{array}$ & $\begin{array}{c}\text { 弾性係数 } \\
\text { [GPa] }\end{array}$ & $\begin{array}{c}\begin{array}{c}\text { 幅 } \\
{[\mathrm{mm}]}\end{array} \\
\end{array}$ & $\begin{array}{l}\text { 板厚 } \\
{[\mathrm{mm}]}\end{array}$ & $\begin{array}{c}\text { 弾性係数 } \\
\text { [GPa] }\end{array}$ & & & \\
\hline S90-P50-50 & 00 & \multirow{4}{*}{11.6} & \multirow{4}{*}{221.0} & \multirow{2}{*}{50} & \multirow{2}{*}{4.45} & \multirow{4}{*}{197.3} & \multirow{2}{*}{1.02} & \multirow{2}{*}{$\begin{array}{c}129 \\
(-100,358) \\
\end{array}$} & 50 \\
\hline $\mathrm{S} 90-\mathrm{P} 50-0$ & 90 & & & & & & & & - \\
\hline S50-P25-100 & \multirow[b]{2}{*}{50} & & & \multirow{2}{*}{25} & \multirow{2}{*}{4.45} & & \multirow[b]{2}{*}{1.12} & \multirow{2}{*}{$\begin{array}{c}181 \\
(-165,527)\end{array}$} & 100 \\
\hline S50-P25-0 & & & & & & & & & - \\
\hline
\end{tabular}

小さいといったメリットがある.

一方，当て板に緊張力を与えて接着すると，緊張力解 放時に当て板端部の接着剂に高いせん断応力と垂直応力 が生じることが示されている9．当て板端部の接着剂に は外力作用時にも高いせん断応力と垂直応力が生じるた め, 当て板に緊張力を与えて接着寸る場合には小さい外 力で当て板がはく離することが示唆されている．緊張力 を導入した当て板のはく離荷重を向上する方法として, 著者らは図-2 に示すような当て板端部に非緊張部を設 ける方法を提案し，理論解析から当て板端部の接着剂に 生じるせん断応力と垂直応力を低減できることを示して いる ${ }^{10)}$ 。この方法では, 緊張力解放時には緊張力導入部 端部，外力作用時には当て板端部でそれぞれ接着剂に生 じる応力が高くなるため，当て板全体に緊張力を与える 場合よりもはく離荷重が向上寸る. 本研究では, 当て板 端部に非緊張部を設けて緊張する装置を開発し，鋼部材 に所定のプレストレスが導入されるか検証する。 また， プレストレスを導入した鋼板の載荷試験を行い, 当て板 端部一非緊張部を設けることによるはく離荷重の向上効 果を検討する.

\section{2. 鋼板へのプレストレスの導入}

\section{(1) 試験体の作製}

緊張力の導入には図-3に示寸装置を用いた. 図-3の 装置は上面に当て板を設置した後，長ネジに設置したナ ットを回転させることによって，当て板の非緊張部を除 く範囲に緊張力を導入できる. 緊張力導入装置と当て板 は四ネジで接合されており，接着面に凹凸が生じないよ うに配慮している. 加工の容易さから, 当て板には鋼板 を用いた. また，試験体の詳細については後述するが， 本研究では当て板の幅方向にできるだけ均一に緊張力が 導入されるように，長さに対して幅の小さい当て板を用 いている.

図-4 に試験体の作製手順を示寸．当て板および母材 鋼板の接着面はグラインダーで研磨して素地出しした後, \#100 のサンドペーパーで目粗し，洗浄および脱脂を行 った. 当て板に緊張力を与えたまま当て板上面に接着剤 を塗布し母材鋼板に接着した．接着後は $20^{\circ} \mathrm{C} の$ 恒温室 で一週間養生した。接着剤の硬化後に当て板に与えた緊 張力を解放し，鋼板にプレストレスを導入した．また， 皿ネジに設置したナットを緩め, 緊張力導入装置を当て 板から除去した.

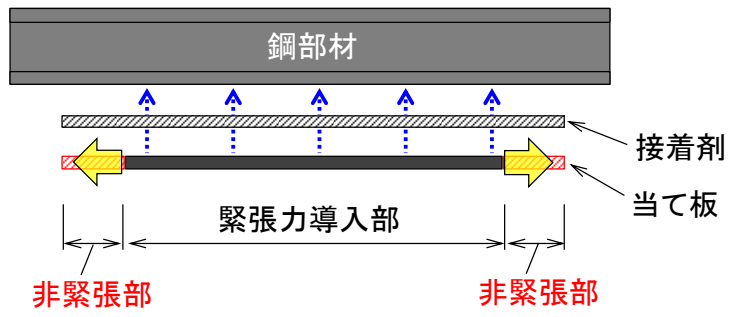

図-2 部分的に緊張力を与えた当て板の接着による 鋼部材へのプレストレスの導入

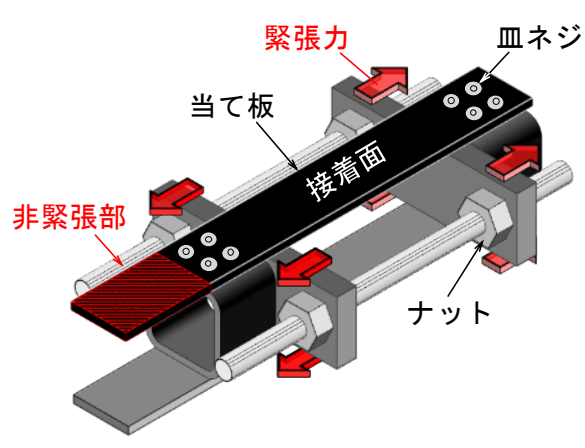

図-3 当て板への緊張力導入装置

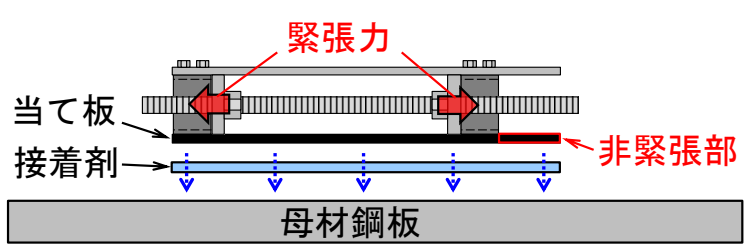

(a) 当て板への緊張力の導入

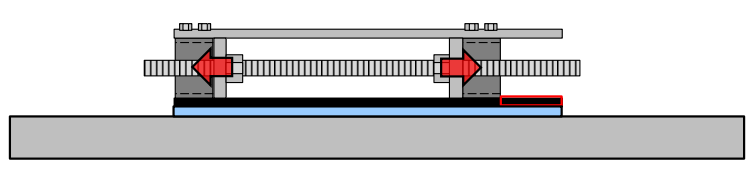

(b) 当て板の接着

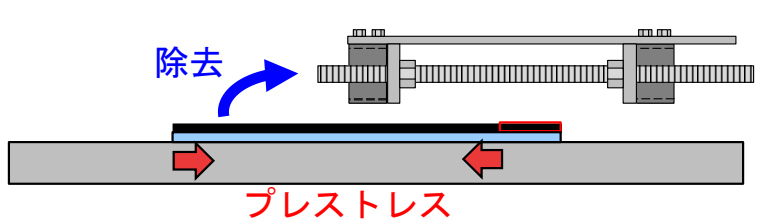

(c) 当て板の緊張力の解放

図-4母材鋼板へのプレストレスの導入 
後の 3 章で示すように, 本研究では試験体を片持ち状 態にセットし, 自由端側に荷重を載荷して当て板のはく 離試験を行う。そこで，はく離が生じる固定端側の当て 板端部のみに非緊張部を設けるように試験体を作製した。

\section{(2) 試験体}

試験体の一覧を表-1 に示す。本研究では緊張力解放 後のひずみの変化が明確に表れるように母材は鋼板とし た. S90-P50 シリーズは母材鋼板が幅 $90 \times$ 厚さ $12 \mathrm{~mm}$, 当て板が幅 $50 \times$ 厚さ $4.5 \mathrm{~mm}, \mathrm{~S} 50-\mathrm{P} 25$ シリーズは母材鋼 板が幅 $50 \times$ 厚さ $12 \mathrm{~mm}$ ，当て板が幅 $25 \times$ 厚さ $4.5 \mathrm{~mm}$ と なっており, シリーズごとに母材鋼板に対する当て板の 曲げ剛性が異なっている. 非緊張部の長さについては, 文献10)を参考に緊張力導入部端部の接着剂に生じるせ 儿断応力が十分に小さくなるように決定し，S90-P50-50 では 50mm，S50-P25-100 では 100mm となっている. 非 緊張部長さの決定方法の詳細は付録(1)に示している. また，はく離荷重を比較するため，それぞれのシリーズ に対して当て板全体を緊張した試験体(末尾が 0)も用い た.

当て板に与える緊張力は, 当て板の緊張部中央の表裏 に貼付したゲージ長 $2 \mathrm{~mm}$ のひずみゲージによって管理 した. 表-1 の括弧内には当て板上面(接着面)および下面 のひずみの值を示している. 当て板皿ネジの接合部で滑 りが生じない範囲で緊張力を与えた結果，S90-P50 シリ ーズでは膜ひずみ成分が $129 \mu, \mathrm{S} 50-\mathrm{P} 25$ では膜ひずみ 成分が $181 \mu$ となった. 一方, 今回の研究で用いた緊張 力導入装置では, 緊張力導入時に当て板中央が緊張力導 入装置側に変形するため, 膜ひずみ成分のみでなく，板 曲げひずみ成分も含まれている，板曲げひずみ成分は S90-P50 シリーズでは $229 \mu$, S50-P25 シリーズでは 346 $\mu$ となっており, 膜ひずみ成分の 1.78 倍および 1.91 倍 となっている. この曲げ変形は, 当て板の緊張力を解放 した後に母材鋼板に正のプレストレスを付与する．ただ し，当て板の曲げ変形によって，当て板中央と端部では 接着剤厚さが均等となっていないと考えられる.

本研究で用いた接着剤は 2 液混合型のエポキシ樹脂で あり，主成分および硬化後の機械的特性は表-2 に示し ている. 本研究でははく離荷重を比較することを目的と しているため, はく離に対して条件が厳しい弾性係数が 大きい接着剤を選定した.

\section{(3) 緊張力の解放によって母材鋼板および当て板に生 じるひずみ}

S50-P25-100 について，当て板への緊張力の導入から 緊張力解放後のひずみを計測した。計測には全てゲージ 長 $2 \mathrm{~mm}$ のひずみゲージを用いている. 当て板の緊張力 の解放後の母材鋼板および当て板のひずみを図-5 に示 す. $x$ 軸は緊張力導入部の中央からの距離となっている. 母材鋼板および当て板のひずみゲージ貼付位置は図-5 に示寸通りである. 2.(2)でも示した通り, 緊張部中央で は当て板の両面にひずみゲージを貼付した．図-5 の灰
表-2 接着剂の材料特性

\begin{tabular}{|c||c|}
\hline 主剤 & エポキシ樹脂 \\
\hline 硬化剤 & 変性ポリアミン \\
\hline 可使時間 & 60 分以上 \\
\hline ガラス転移点 $T_{g}\left[{ }^{\circ} \mathrm{C}\right]$ & 40 \\
\hline 弾性係数 $E_{e}[\mathrm{GPa}]$ & 6.50 \\
\hline せん断弾性係数 $G_{e}[\mathrm{GPa}]$ & 2.39 \\
\hline ポアソン比 & 0.36 \\
\hline $\begin{array}{c}\text { 引張強さ }[\mathrm{MP}] \\
\text { (規格值, JSKK7113-1995による) }\end{array}$ & 20 以上 \\
\hline $\begin{array}{c}\text { 引張せん断強度 }[\mathrm{MP}] \\
\text { (規格值, JSK6850-1994による) }\end{array}$ & 14 以上 \\
\hline
\end{tabular}



(a) 母材鋼板

緊張部中央

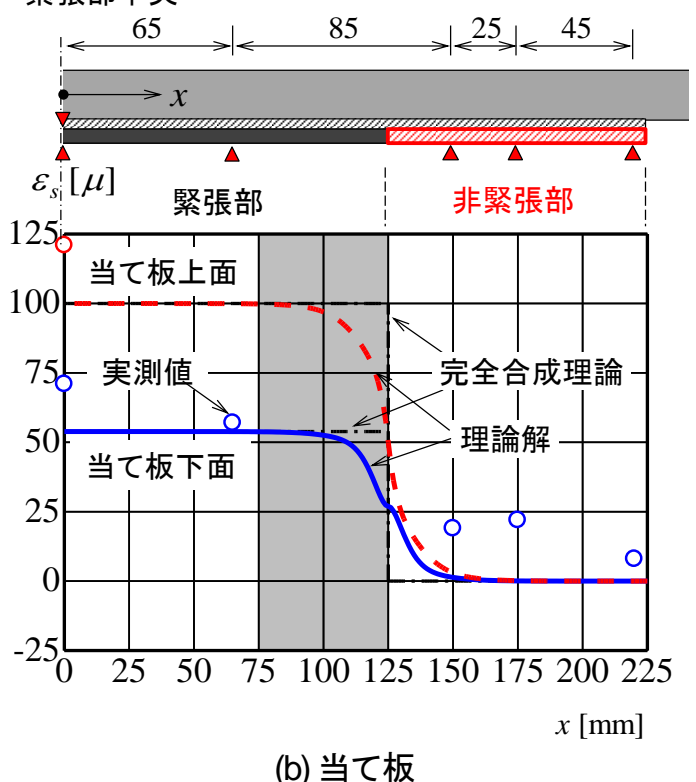

図-5＼cjkstart当て板の緊張力解放によって生じるひずみ 
色でハッチングされている範囲は当て板が緊張力導入装 置に接合されている範囲であり，この範囲では当て板に 与えた緊張力の大きさが一定になっていないと考えられ る.

図-5 の一点鎖線は母材鋼板と当て板が完全に合成さ れているとしたときのひずみの計算值であり，次式で表 される。

$$
\begin{gathered}
\varepsilon_{s}=\left\{\begin{array}{cc}
-\frac{P_{\text {pre }}}{E_{s} A_{v}}+\frac{M_{\text {pre }}}{E_{s} I_{v}} y_{v} & \left(0 \leq x \leq l_{p}\right) \\
0 & \left(l_{p} \leq x \leq l\right)
\end{array}\right. \\
\varepsilon_{p}=\left\{\begin{array}{cc}
-\frac{P_{\text {pre }}}{E_{p} A_{v}}+\frac{M_{p r e}}{E_{p} I_{v}} y_{v}+\varepsilon_{p r e} & \left(0 \leq x \leq l_{p}\right) \\
0 & \left(l_{p} \leq x \leq l\right)
\end{array}\right.
\end{gathered}
$$

ここに,

$$
\begin{gathered}
M_{\text {pre }}=P_{p r e} a_{p} \\
P_{\text {pre }}=E_{p} A_{p} \varepsilon_{\text {pre }}
\end{gathered}
$$

$\varepsilon_{s}, \varepsilon_{p}:$ 母材鋼板および当て板のひずみ,

$E_{s}, E_{p}$ : 母材鋼板および当て板の弾性係数,

$A_{p} \quad$ : 当て板の断面積,

$A_{v}$ : 母材鋼板と当て板の合成断面の断面積,

$I_{v}$ : 母材鋼板と当て板の合成断面の断面二次モ ーメント,

$y_{v}$ : 母材鋼板と当て板の合成断面の中立軸から の距離(下向きを正とする),

$a_{p}$ : 母材鋼板と当て板の合成断面の中立軸から 当て板の図心までの距離,

$x$ : 当て板中央からの距離,

$l_{p} \quad$ : 当て板緊張部の半長さ,

$l$ : 当て板緊張部中央から当て板端部までの長 さ,

$\varepsilon_{\text {pre }}$ : 緊張力によって当て板に与えたひずみ(膜ひ ずタ成分).

図-5 に示す実線および破線は接着剤のせん断方向と 垂直方向の変形を考慮して求めたひずみの理論解である. 母材鋼板および当て板のひずみは次式より求めた.

$$
\begin{gathered}
\varepsilon_{s}(x)=\frac{N_{s}(x)}{E_{s} A_{s}}+\frac{M_{s}(x)}{E_{s} I_{s}} y_{s} \\
\varepsilon_{s}(x)=\frac{N_{p}(x)}{E_{p} A_{p}}+\frac{M_{p}(x)}{E_{p} I_{p}} y_{p} \\
=-\frac{N_{s}(x)}{E_{p} A_{p}}+\frac{N_{s}(x) a-M_{s}(x)}{E_{p} I_{p}} y_{p}
\end{gathered}
$$

ここに，

$N_{s}, N_{p}$ : 母材鋼板および当て板の軸力,
$M_{s}, M_{p}$ : 母材鋼板および当て板の曲げモーメント,

$A_{s} \quad$ : 母材鋼板の断面積,

$I_{s}, I_{p}$ : 母材鋼板および当て板の断面二次モーメ ント,

$y_{s}, y_{p}$ : 母材鋼板および当て板の図心からの距離 (下向きを正とする)

$a$ : 母材鋼板と当て板の図心間の距離.

式(5)および式(6)に用いる母材鋼板の軸力と曲げモー メントは，微小区間の釣合いから導出される母材鋼板の 軸力およびせん断力に関する微分方程式の解を用いて得 られる。文献10)では，端部に非緊張部を設けた当て板 を接着した単純支持の鋼部材に対して等曲げモーメント が作用する場合を対象に，鋼部材の軸力およびせん断力 の理論解を与えている. 当て板の緊張力解放時に母材鋼 板に生じる軸力およびせん断力の理論解は，文献10)で 与えられている理論解において作用曲げモーメントを 0 とすることによって次式で得られる.



$$
V_{s}(x)=\left\{\begin{array}{l}
Y_{1} \cosh (\omega x) \sin (\omega x) \\
+Y_{2} \sinh (\omega x) \cos (\omega x) \\
+\frac{W X_{1}}{c^{2}} \sinh (c x) \quad\left(0 \leq x \leq l_{p}\right) \\
Y_{3} \cosh \left\{\omega\left(x-l_{p}\right)\right\} \cos \left\{\omega\left(x-l_{p}\right)\right\} \\
+Y_{4} \cosh \left\{\omega\left(x-l_{p}\right)\right\} \cos \left\{\omega\left(x-l_{p}\right)\right\} \\
+Y_{5} \sinh \left\{\omega\left(x-l_{p}\right)\right\} \sin \left\{\omega\left(x-l_{p}\right)\right\} \\
+Y_{6} \sinh \left\{\omega\left(x-l_{p}\right)\right\} \cos \left\{\omega\left(x-l_{p}\right)\right\} \\
+\frac{W X_{1}}{c^{2}} \cdot \frac{\sinh \left(c l_{p}\right)}{\cosh \left(c l_{n}\right)} \cdot \cosh \{c(l-x)\} \\
\end{array}\right.
$$

ここに

$$
\begin{aligned}
& X_{1}=\frac{\cosh \left(c l_{n}\right)}{\cosh (c l)} \cdot \frac{G_{e} b_{p}}{h c^{2}} \varepsilon_{\text {pre }} \\
& X_{2}=\frac{\tanh \left(c l_{p}\right)}{1+\tanh \left(c l_{p}\right) \tanh \left(c l_{n}\right)} \cdot \frac{G_{e} b_{p}}{h c^{2}} \varepsilon_{\text {pre }} \\
& X_{3}=-\frac{\tanh \left(c l_{p}\right) \tanh \left(c l_{n}\right)}{1+\tanh \left(c l_{p}\right) \tanh \left(c l_{n}\right)} \cdot \frac{G_{e} b_{p}}{h c^{2}} \varepsilon_{p r e} \\
& {\left[\begin{array}{llllll}
Y_{1} & Y_{2} & Y_{3} & Y_{4} & Y_{5} & Y_{6}
\end{array}\right]^{\mathrm{T}}=\underset{6 \times 6}{\Omega_{1}^{-1}} \underset{6 \times 1}{\Omega_{2}}}
\end{aligned}
$$


表-3 はく離荷重，はく離曲げモーメントおよび接着剤に生じる主応力

\begin{tabular}{|c|c|c|c|c|c|c|c|c|}
\hline \multirow{3}{*}{ 試験体 } & \multirow{3}{*}{$\begin{array}{c}\text { はく離荷重 } \\
{[\mathrm{N}]}\end{array}$} & \multirow{3}{*}{$\begin{array}{c}\text { はく離 } \\
\text { 曲げモーメント } \\
{[\mathrm{N} \cdot \mathrm{m}]}\end{array}$} & \multicolumn{6}{|c|}{ 接着剤に生じる主応力 [MPa] } \\
\hline & & & \multicolumn{2}{|c|}{ 緊張力の解放 } & \multicolumn{2}{|c|}{ 曲げモーメント } & \multicolumn{2}{|c|}{ 合計 } \\
\hline & & & $x=l_{p}$ & $x=l$ & $x=l_{p}$ & $x=l$ & $x=l_{p}$ & $x=l$ \\
\hline S90-P50-50 & 702 & 246 & 1.8 & 0 & 0.4 & 36.5 & 2.2 & 36.5 \\
\hline S90-P50-0 & 497 & 174 & - & 4.9 & - & 25.8 & - & 30.7 \\
\hline S50-P25-100 & 276 & 110 & 2.5 & 0 & 0.2 & 29.1 & 2.7 & 29.1 \\
\hline $\mathrm{S} 50-\mathrm{P} 25-0$ & 181 & 72 & - & 6.7 & - & 19.1 & - & 25.8 \\
\hline
\end{tabular}

$$
\begin{gathered}
c=\sqrt{\frac{b_{p} G_{e}}{h} \cdot \frac{1}{K Z_{1}} \cdot \frac{a^{2}}{E_{s} I_{s}}} \\
K=\frac{1}{1+Z_{1} Z_{2} r_{s}^{2} / a^{2}} \\
Z_{1}=1+\frac{I_{p}}{n I_{s}} \\
Z_{2}=1+\frac{n A_{s}}{A_{p}} \\
r_{s}=\sqrt{\frac{I_{s}}{A_{s}}} \\
n=\sqrt[4]{\frac{b_{p} E_{e}}{4 h} \cdot \frac{Z_{1}}{E_{p} I_{p}}} \\
J=d_{p}-\left(Z_{1}-1\right) d_{s}
\end{gathered}
$$

$l_{n} \quad$ : 当て板非緊張部の長さ,

$d_{s} \quad$ : 母材鋼板の図心から下面までの距離,

$d_{p} \quad$ : 当て板の図心から上面までの距離,

$b_{p} \quad$ : 当て板の幅(接着幅),

$h$ : 接着㓮の厚さ,

$E_{e}, G_{e}$ : 接着風の弾性係数およびせん断弾性係数,

$\Omega_{1} \quad$ : 境界条件に関与る 6 行 $\times 6$ 列の行列(付録(2) 参照),

$\Omega_{2}$ : 外力および緊張力に関する 6 行 $\times 1$ 列のべ

$$
\text { クトル(付録(2)参照). }
$$

当て板の緊張力を解放することによって母材鋼板に生 じる曲げモーメントの理論解は次式となる.

$$
M_{s}(x)=\frac{N_{s}(x) a}{Z_{1}}-\frac{1}{4 \omega^{4}} \cdot \frac{d^{3} V_{s}(x)}{d x^{3}}
$$

式(5)および式(6)に式(7)，(22)を代入することによって， 緊張力解放時に母材鋼板および当て板に生じるひずみの 理論解が得られる.

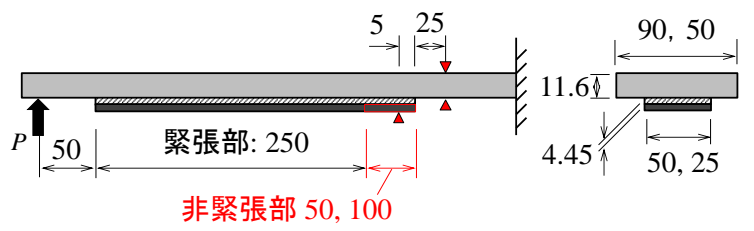

(a) S90-P50-50, S50-P25-100



(b) S90-P50-0, S50-P25-0

図-6 載荷方法



図-7 はく離曲げモーメント

図-5 には式(1)，(2)の完全合成理論や式(5)，(6)から求 められるひずみの理論解を示している，S50-P25-100 で は当て板の緊張部と非緊張部の境界から $25 \mathrm{~mm}$ 程度の範 囲で両者の違いが大きくなっている. 母材鋼板および当 て板のひずみの実測值はそれぞれ，完全合成理論や理論 解よりも若干圧縮側および引張側にシフトしている.こ れは 2.(2)でも示したように，当て板への緊張力導入の 際に当て板に板曲げひずみ成分が生じたためと考えられ る. 但し，実測したひずみ分布の全体的な傾向は完全合 成理論や理論解と近くなっている.

\section{3. 当て板のはく離試験}

\section{（1）載荷方法}

非緊張部を設けることによる当て板のはく離荷重向上 
効果を検証するため, 当て板のはく離試験を行った. 載 荷方法は図-6に示す通り，母材鋼板を片持ち状態で架台 に固定し，当て板接着面が引張側となるように試験体下 面から載荷した．各シリーズで，はく離が生じる固定端 側の当て板端部の位置に作用する曲げモーメントが等し くなるように載荷位置を決定した。 S90-P50シリーズで は載荷位置から固定端側当て板端部までの距離が $350 \mathrm{~mm}$, S50-P25シリーズでは400mmとなっている. 当て板接着 鋼板が曲げモーメントによってはく離するとき，当て板 は端部から徐々にはく離するためはく離荷重が明確に表 れない場合がある ${ }^{11)}$. 本研究では，当て板端部から $5 \mathrm{~mm}$ の位置にひずタゲージを設置し，ひずみの值が低下し始 めた荷重をはく離荷重とした。

\section{(2) はく離曲げモーメント}

当て板がはく離したときの荷重を表-3に示している. また図-7には当て板がはく離したときの固定端側の当て 板端部の曲げモーメント $M$ (以下, はく離曲げモーメン トとする）を示している. この図から，S90-P50シリー ズおよびS50-P25シリーズに対して，非緊張部を設ける ことで当て板のはく離曲げモーメントがそれぞれ 1.41 倍 および1.53倍向上していることがわかる，また，当て板 に与えた緊張力が大きいS50-P25シリーズの方がはく離 曲げモーメントの向上効果が大きくなっている.

\section{(3) 接着剂に生じる応力}

はく離荷重の向上効果を定量的に評価するため, 非 緊張部の有無が接着剤に生じるせん断応力や垂直応力に 与える影響を検討する.

緊張力を解放することによって接着剤に生じるせん 断応力 $\tau$ および垂直応力 $\sigma_{y}$ は式(7)および式(8)で示した 鋼板の軸力およびせん断力を用いて次式で与えられる

$$
\begin{gathered}
\tau=-\frac{1}{b_{p}} \cdot \frac{d N_{s}}{d x} \\
\sigma_{y}=-\frac{1}{b_{p}} \cdot \frac{d V_{s}}{d x}
\end{gathered}
$$

図-8 に S50-25 シリーズの接着剤に生じるせん断応力 および垂直応力の分布を示している，この図から，非緊 張部を設けない S50-P25-0 では，当て板端部で接着剤に 高いせん断応力と垂直応力が生じていることがわかる. 非緊張部を設けずに接着した場合, 緊張力を解放するこ とによって当て板端部の接着剤に生じるせん断応力およ び垂直応力は次式となる9).

$$
\bar{\tau}(l)=-\frac{G_{e}}{h c} \varepsilon_{\text {pre }}
$$

\section{$\tau[\mathrm{MPa}]$}



(a) せん断応力

$$
\sigma_{y}[\mathrm{MPa}]
$$

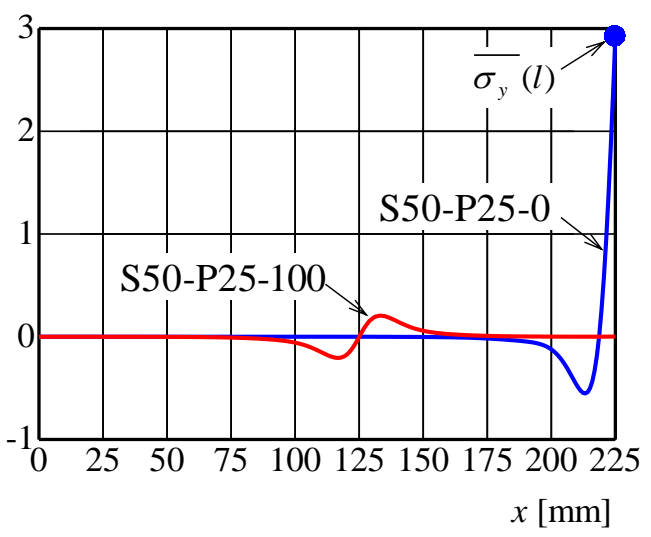

(b) 垂直応力

図-8 当て板の緊張力解放によって接着剤に生じる せん断応力と垂直応力(S50-P25 シリーズ)

$$
\overline{\sigma_{y}}(l)=W\left\{1-\frac{2 \omega}{c}-\frac{1}{2}\left(\frac{c}{\omega}\right)^{2}\right\} \bar{\tau}(l)
$$

一方，当て板端部に十分に長い非緊張部を設けること によって，接着剤に生じるせん断応力と垂直応力は 0 に 収束する ${ }^{10)}$. 非緊張部の長さの詳細な決定方法について は付録(2)に示している。 また，図-8 からわかるように 非緊張部を設けた場合には $x=l_{p}$ の位置で接着剂に生じ るせん断応力が最大となっている. 非緊張部が十分に長 い場合， $x=l_{p}$ の位置の接着剤に生じるせん断応力は次 式に収束する ${ }^{10)}$.

$$
\bar{\tau}\left(l_{p}\right)=-\frac{G_{e}}{2 h c} \varepsilon_{p r e}
$$

図-8にプロットしている式(25)〜(27)の収束式は式(23), (24)の理論解にほぼ一致しており, 収束式の妥当性が確 認できる.

片持ち状態の当て板接着鋼板に上向きの荷重が作用 することによって接着剤に生じるせん断応力と垂直応力 は，非緊張部の有無に関わらず，固定端側の当て板端部 で最大となる．当て板が十分に長いとき，固定端側の当 
て板端部の接着剂に生じるせん断応力と垂直応力は当て 板端部の位置に作用するせん断力と曲げモーメントの関 数として次式に収束する ${ }^{12)}$.

$$
\begin{gathered}
\tau_{e}=-\frac{c K}{a b_{p}}\left(M_{e}-\frac{1}{c} Q_{e}\right) \\
\sigma_{y e}=\frac{\omega}{b_{p}}\left[W \frac{K}{a}\left\{2+\frac{1}{2}\left(\frac{c}{\omega}\right)^{3}-\frac{c}{\omega}\right\} M_{e}\right. \\
\left.+2 \omega\left(1-\frac{1}{Z_{1}}\right) M_{e}-2\left(1-\frac{1}{Z_{1}}+\frac{J K}{a Z_{1}}\right) Q_{e}\right]
\end{gathered}
$$

$Q_{e}, M_{e}$ : 固定端側の当て板端部に位置に作用するせ ん断力および曲げモーメント.

著者らはこれまでに当て板接着鋼部材の当て板のは く離に対する統一的な破壊基準を検討しており，接着剤 に生じる主応力を用いて当て板のはく離を評価できる可 能性を示している ${ }^{11)}$. 本研究では固定端側の当て板端部 の接着剤に生じるせん断応力と垂直応力から主応力を算 出し，はく離の抑制効果を荷重を定量的に評価する．接 着剤に生じる主応力は次式で与えられる.

$$
\sigma_{p}=\frac{\sigma_{y}}{2}+\sqrt{\left(\frac{\sigma_{y}}{2}\right)^{2}+\tau^{2}}
$$

表-3に当て板の緊張力を解放することによって $x=l_{p}$ および $x=l$ の位置の接着剤に生じる主応力を示してい る. 緊張部を設けていないS90-P50-0および50-P25-0では, 当て板の緊張力を解放することによって当て板端部の接 着剤にそれぞれ4.9MPaおよび6.7MPaの主応力が生じてい る. 当て板がはく離したとき, 荷重による主応力との和 はそれぞれ30.7MPaおよび25.8MPaであり，緊張力の解放


一方，非緊張部を設けた場合，当て板端部の接着剤に生 じる主応力は荷重の作用によるもののみを示している. また， $x=l_{p}$ の位置では緊張力の解放および荷重の作用 の両方によって主応力が生じるが，その值は当て板端部 で荷重の作用のみによって生じる主応力よりも小さい. 本研究では各試験体に対して試験体が1体ずつと少なく, はく離時の当て板端部の接着剂に生じている主応力は 25.8〜36.5MPaとばらつきが大きくなっている.

\section{4. まとめ}

本研究では，当て板に緊張力を与えて鋼板に接着す る場合を対象に，当て板の端部に非緊張部を設けること による当て板のはく離抑制効果について検討した．本研 究の条件下で得られた結果を以下に記す。

1）端部に非緊張部を設けた当て板を母材鋼板に接着 した場合でも，当て板の緊張部の母材鋼板には完 全合成理論から算出されるひずみと同程度のひず タが導入された。
2）当て板全体を緊張した場合と端部に非緊張部を設 けた場合のはく離荷重を比較すると，当て板端部 に非緊張部を設けた方がはく離荷重が大きくなっ た.

3) 接着剤に生じる主応力を用いて当て板のはく離荷 重を評価した。当て板全体に緊張力を与える時, 緊張力解放後に接着剤に生じる主応力によって, はく離荷重が低減したと考えらる.

4) 非緊張部を設ける場合, 緊張力解放によって接着 剤に生じる主応力が最も高くなるのは，緊張部と 非緊張部の境目の位置である，ただし，その值は， 荷重の作用によって当て板端部に生じる主応力よ りも小さい.

謝辞 : 試験体の作製にあたつては，コニシ株式会社の堀 井久一様より接着剤をご提供いただきました。ここに感 謝の意を記します。

\section{付録}

\section{(1) 非緊張部の長さの決定方法}

当て板端部に非緊張部を設けた場合に，接着剤に生じ るせん断応力の絶対值は緊張力導入部端部で最大となり， その值は非緊張部が十分に長くなると式(27)に収束する。 また，非緊張部を設けない場合に緊張力導入部端部のせ ん断応力の絶対值が最大となり，その值は式(24)となる

文献10)では，緊張力導入部端部の接着剤に生じるせ ん断応力の絶対值が式(27)に近くなるように，次式を用 いて必要非緊張部長さの決定している.

$$
l_{n} \geq-\frac{1}{c} \ln (\lambda)
$$

ここに， $\lambda$ は緊張力導入部端部の接着剤に生じるせん 断応力が式(27)に収束する精度を表している. 非緊張部 の長さを決定する際には入に0に近い正の值を代入する. 式(A1)には，式(13)に示す係数 $c$ が含まれており，母材 鋼板に対する当て板の曲げ岡性や，接着剤厚さが大きく なるほど必要非緊張部長さは大きくなる.

本研究では，試験体を作製するにあたって， $\lambda=0.01$, 接着剤の厚さを $0.5 \mathrm{~mm}$ として式(A1)から必要 な非緊張部長さを算出した。 それぞれの必要非緊張部長 さはS90-P50シリーズでは40.3mm, S50-P25シリーズでは 41.6mmであり，試験体では作製の都合上，算出結果よ りも大きい50mmおよび100mmとした。

\section{（2）境界条件に関する行列および外力と緊張力に関す るベクトル}

式(12)に用いる境界条件に関する行列 $\Omega_{1}$ および外力と 緊張力に関するベクトル $\Omega_{2}$ をそれぞれ式(A2)および式 (A3)に示す. 


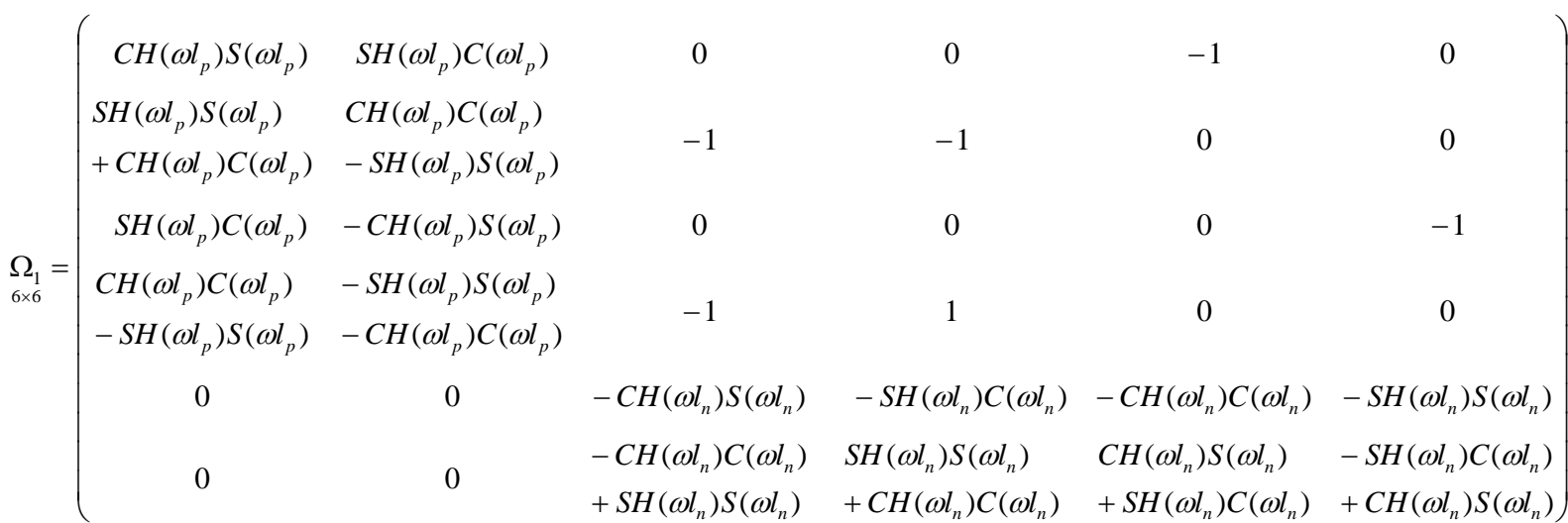

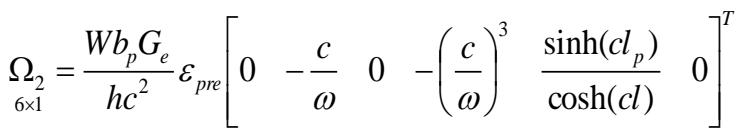

\section{参考文献}

1) 渡邊憲市，板垣一也，鈴木博之 : 炭素繊維強化樹脂板に よる鋼橋の補強，鋼構造年次論文報告集，第 8 巻，2000

2) Miller, T.C., Chajes, M.J., Mert, D.R. and Hastings, J. N.: Strengthening of a steel bridge girder using CFRP plates, Journal of Bridge Engineering, ASCE, USA, Vol.6,pp.514-522, 2001.

3) Moy, S.S.J. and Bloodworth, A.G.: Strengthening a steel bridge with CFRP composites, Proceedings of the Institution of Civil Engineers, Structures \& Buildings 160 Issue SB2, pp.81-93, 2007.

4) 森下太陽，藤井堅，森田和也，堀井久一，中村秀治 : 腐 食した鋼板の鋼板接着による性能回復，構造工学論文集, Vo.57A, pp.747-755, 2011.

5) 植村有馬，藤井堅，井上太郎：繰り返し軸力を受ける鋼 板接着補強された腐食鋼板の而讨久性，構造工学論文集， Vol.60A, pp.554-563, 2014.

6) 濱田譲, 安森浩, 小林朗, 葛目和宏 : 炭素繊維プレート 緊張材によるコンクリート構造物の補強，コンクリート 工学, Vol..43, No.8, pp.17-24, 2005.

7) 立神久雄, 長谷川岡, 栗田幸治, 井上浩男 : 炭素繊維プ レート緊張剤を用いた構造物の補強工法(アウトプレート
工法)，三井造船技報，No.201，pp.35-40，2010

8) Luke, S., Darby, J. and Skwarski, A.: Using stressed and unstressed composite plates for strengthening existing strucutures, Proceedings of the Eighth International Conference on Fibre Reinforced Composites, pp.35-40, 2000 .

9) 石川敏之 : プレストレスが導入された CFRP 板接着鋼部 材のはく離曲げモーメント, 構造工学論文集, Vol.56A, pp.991-998，2010.

10）清水優，石川敏之，服部篤史，河野広隆 : プレストレス 導入 CFRP 板接着鋼部材のはく離曲げモーメント向上法 の提案，土木学会論文集 A2(応用力学)，Vol.67，No.2(応 用力学論文集 Vol.14)，I_777-I_784，2011.

11) Shimizu, M., Ishikawa, T., Hattorri, A. and Kawano, H.: Failure criteria for debonding of patch plate bonded onto steel members subjected to bending, Journal of JSCE, Vol.2, No.1, 2014.

12）石川敏之，清水 優，服部篤史，河野広隆 : 作用外力が CFRP 板接着鋼部材の接着剤に生じる応力に与える影響, 土木学会論文集 A2 (応用力学)，Vol.68，No.2（応用力 学論文集 Vol.15），pp.I_715-I_726， 2012.

(2015.6. 23 受付)

\title{
DEBONDING BENDING MOMENT OF PARTIALLY PRE-TENSIONED PATCH PLATE BONDED TO STEEL PLATE
}

\author{
Masaru SHIMIZU, Toshiyuki ISHIKAWA, Atsushi HATTORI \\ and Hirotaka KAWANO
}

For strengthening of steel members suffering deterioration and/or insufficiency of load carrying capacity, externally bonding patch plate have been used. Furthermore, pretensioned patch plate have also been used in several strengthening cases. Although the pretensioned patch plate can improve stress in steel member not only by live load but also dead load, the shear and normal stress tend to be introduced in adhesive layer. The stresses may cause the reduction of debonding load of patch plate. To improve the debonding load of pretensioned patch plate, applying non-pretensioned region at the end of patch plate 
was proposed. In this study, prestress introduced into steel plate by partially pre-tensioned patch plate was observed. In addition, the improvement of debonding load due to the non-pretentioned region is confirmed from debonding tests. The improvement effect in the debonding load is evaluated from the view of principal stress in adhesive. 